\title{
The Effectiveness of Guessing Word Learning Model Type towards the Elementary Students' Natural Science Learning Outcomes
}

\author{
Siti Aisyiyah ${ }^{1}$, Ay. Soegeng 2 , Filia Prima ${ }^{3}$
}

${ }^{123}$ Education Faculty, University of PGRI Semarang, Indonesia

\section{A R T I C LE I N F O \\ Article history: \\ Received 18 March 2020 \\ Received in revised form \\ 30 April 2020 \\ Accepted 5 May 2020 \\ Available online 15 May \\ 2020}

Kata Kunci:

Keywords:

Guessing word,

effectiveness

\begin{abstract}
A B S T R A K
Rendahnya hasil belajar pelajaran IPA siswa kelas IV SD Negeri Kedungpucang Purworejo., hal ini disebabkan oleh beberapa fakor luar dan factor dalam. Factor dalam berasal dari diri siiswa dan factor luar bersal dari luar siswa. Tujuan penelitian ini adalah untuk mengetahui keefektifan model pembelajaran kooperatif tipe tebak kata terhadap hasil belajar siswa kelas IV SD. Jenis penelitian ini adalah penelitian kuantitatif dengan desain posstest. Populasi penelitian ini adalah siswa kelas IV yang berjumlah 40 orang yang diperoleh dari teknik sampling. Data dikumpulkan dengan observasi, wawancara, tes, dan dokumentasi. Hasil analisis perhitungan uji $t$ diperoleh thitung 3,2062 , dengan dk $=(\mathrm{n} 1+\mathrm{n} 2-2)=20+20-2=38$ dan taraf signifikan $5 \%$ dengan harga $\mathrm{t}(1 / 2 \alpha ; 38)$ diperoleh $t_{\text {tabel }}=2,0244$. Karena thitung $\geq t_{\text {tabel }}$ yaitu $3,2062 \geq$ 2,02809 maka H0 ditolak. Jadi, model kooperatif tebak kata dapat meningkatkan hasil belajar IPA kelas IV. Dengan adanya model ini akan membatu guru untuk menginovasi pembelajaran sehingga hasil belajar yang diinginkan dapat dicapai.
\end{abstract}

\section{A B S T R A C T}

The low natural science learning outcomes of the students' grade IV of SD Negeri Kedungpucang Puworejo was caused by external and internal factors. Intern factors came from the students' side individuals and external factors came from the students' outside of individuals. The purpose of this study was to determine the effectiveness of the cooperative learning model that is guessing word towards the natural science learning outcomes of the elementary school students grade IV. The present research was quantitative research using a posttest as the design. The population of the research was the 40 students of IV grade which obtained through sampling. The data was obtained using observation, interview, test, and documentation. The analysis result obtained with t-test was t-count 3,2062, with $\mathrm{dk}=(\mathrm{n} 1+\mathrm{n} 2-2)=20+20-2=38$ and the significant level of $5 \%$ with price $t(1 / 2 \alpha ; 38)$ was obtained $t$-table $=2,0244$. Because $t$-count $\geq t$-table is $3,2062 \geq 2,02809$ so $H 0$ was rejected. In conclusion, the learning cooperation model of guessing words can improve the natural science learning outcomes of the students of IV grade. The implementation of the learning model will help the teachers to innovate the learning activity so the learning outcomes can be reached optimally based on the expectation.

\section{Introduction}

Learning outcomes is the result that the students obtain after passing the learning process; cognitive, affective, and psychomotor. Learning outcomes is the abilities student has after he acquires his learning experience (Sudjana, 2010: 22 (Syamsiyah \& Wedyawati, 2017)). (Widia Hapnita, Rijal Abdullah, Yuwalitas Gusmareta, 2018) state that the learning outcomes are something that is obtained, mastered, or own by the student after learning. Meanwhile, (Ahmad, 2013) argues that there are three aspects of learning outcomes; cognitive, affective, and psychomotor. The success of students' learning outcomes is influenced by both internal and external factors. External factors come from outside the student that how the learning process is carried out towards his learning outcomes.

The learning process is an interactive process that comes from all directions which carried out by the student helped by learning resources. The learning process is an interactive process between 
the students and the teacher with varied learning components programmed by the teacher to reach certain programmed objectives. Omar Malik (2013) (Dolong, 2016) states that learning is a combination of students, teachers, and learning resources as well as the facilities to reach certain programmed objectives. A successful learning process is when students can acquire certain basic competencies. It can be manifested only if the learning process is designed well and can include the interaction between the teacher and the students and can manifest interactive, conducive, inspirative, happy, and comfortable. The learning process is an activity that must be well-planned and designed following the certain steps procedure, thus the implementation can reach the expected result (Asmadawati, 2014). The process of learning is efficient, effective, and interesting if the learning is designed with systematic procedures. A learning system design seeks to create a learning process that can help individuals to achieve the learning process that can help individuals achieve optimal competence, (Zein, 2016). A successful learning process is learning that fulfill the criteria such as between instructors and educators interact intensively with learning resources, conducted exercises for mastery of competencies to obtain feedback after doing the learning process in other words learning is a process of creating students who learn to achieve goals, (Marlina, 2017). Problems then come after the learning process is implemented based on the teacher's scenario but yet optimally conducted which is shown by the learning outcomes of the students that have not reflected the planned passing grade (KKM). The problem appears because of the rapid natural science and technology development which pushes the teacher to be more innovative in the implementation of learning and teaching. But, the teacher still uses an old model that makes the students do not study but that makes them become good listeners. The teaching and learning that have been implemented only focuses on the formation of uniformity behavior, with the hope of producing order, obedience, and certainty (Dedeng (Zein, 2016)). The argument was supported by the preliminary observation that was carried out in di SD Negeri Kedungpucang Purworejo, Jalan Magelang km 10 Bener Purworejo.

The researcher chose SD Kedungpucang as the setting was based on several reasons, such as the strategic location where it is located on the outskirts of the city and is located near a major road which allows noise caused by the sound of motorized vehicles and the learning used is still possible to use lecture methods that cause students to become bored and talk to themselves. As an interview conducted with Ms. Victy Vidaya Viqraizin S.Pd as the fourth-grade guardian on August 2, 2019 researchers found several problems. Among these problems are learning in students playing alone or talking with their classmates so that the material delivered is not sufficient, students lack interest in learning, lack of students' role in teaching and learning for example when group activities are only a few students who are active in following, and the teacher has not applied a variety of learning models when the learning process takes place. So students feel boredom during the learning process and students are less interested in focusing attention on the material delivered by the teacher. Problems that arise this result in low student learning outcomes. Learning outcomes in natural science subjects at SD Negeri Kedungpucang Purworejo are low. the low learning outcomes can be seen from the evaluation value of students who are less than the KKM (Minimum Graduation Criteria) that has been set is 60. And some students have problems regarding lack of confidence. Based on the description of the problem, this learning process is not only influenced by the model or the method of teaching the teacher, but some aspects of learning take justice in the weaknesses of the learning process. If this problem is allowed to be based on the progress of the learning process and the development of knowledge both cognitive, psycho-Patric, and effective students. To overcome this, offer several alternative solutions, one of which can be done by the teacher is to use an innovative model. The learning model is a pattern that is used as a guide in planning learning in class and tutorials (Agus Suprijono, 2014). The choice of the correct learning process is really important so it can obtain the expected result (Rencus B. Sinabariba, 2017). Thus, the researcher chose the cooperative learning model guessing word type.

Guess the word learning model is one example of cooperative learning in which the learning process guesses a word by mentioning certain words until the words mentioned are correct (Hanif Mukhlas, 2018). Guess the word model is a game-based cooperative learning model that matches the character of elementary school students (Syamsiyah \& Wedyawati, 2017). (Ryantika, et., al., 2016 (Adkhilni \& Mulyadiprana, 2018) states that the guess word model is a learning model is a cooperative model that emphasizes more on making vocabulary students more students because students are required to answer questions in the form of few clues. The uniqueness of the word guessing model makes students more active and makes the learning process more fun (Adkhilni \& Mulyadiprana, 2018). So the word guessing model is one of the cooperative models that is packed with word guessing games where students are required to guess the whole word by arranging or completing words with letters. With this model, students will be more active in the learning process and students will increase 
knowledge about word vocabulary, the development of the ability to work together, and develop the ability to think and the ability to submit an opinion (Suryadi, 2019). The argument is supported by (Fadhillah, 2019) who says that guess the word model can increase student motivation in finding words to be arranged in sentence form. So, guess the word model has several advantages compared to other models.

(Kurniasih, 2017) state that guess the word model has several advantages namely, children will have a wealth of languages, very interesting so that each student wants to try it, students become interested in learning, and makes it easy to instill the concept of learning in students' memories. The strength of the guesswork model is also supported by several studies. Where the studies stated that the general guess of the word guess model will have a positive impact on the learning process because students actively find and arrange knowledge about word literacy, the learning process is more fun because students play in learning (Fadhillah, 2019; Ferianti \& Hamzah, 2018; Suryadi, 2019). The success of the guessing word learning model is inseparable from the steps of learning that are carried out. Suprijono (Suryadi, 2019) argues that guess the word learning model steps are: 1) The teacher explains the competencies to be achieved or material approximately 45 minutes. 2) The teacher tells students to stand in pairs in front of the class. 3) A student is given a card measuring $10 \times 10 \mathrm{~cm}$ which his partner will read out later. Another student is given a $5 \times 2 \mathrm{~cm}$ card whose contents cannot be read (folded) then placed on the forehead or tucked in the ear. 4) While students carry a $10 \times 10 \mathrm{~cm}$ card read out the words written in it while the partner guesses what is meant in the $10 \mathrm{x} 10 \mathrm{~cm}$ card, the right answer if it matches the contents of the card affixed to the forehead or ears. Seeing the advantages possessed by the guesswork model, many studies have been done before.

The research conducted by (Mursidik et al., 2015) found that the word guessing model had an effect on student learning outcomes on simple aircraft material class V SDN 02 Lengkenat this was seen based on the $t$-test where $t$ count was greater than $t$ table namely 2.816>2.042. (Fitri et al., 2018) There is an influence of guessing learning models supported by comic media on Indonesian language learning outcomes describing animals around their characteristics using sentences that are easily understood in grade II students of SDN III Panjerejo Academic Year 2016/2017 this is evident from the value of t-count 5,947 greater than table $1 \%$ is 1.2931 . While the Experimental group's mean test is 85.5263. While the mean test of the control group is 72.9474. (Hanif Mukhlas, 2018) states that the effectiveness of the guesswork learning model on learning outcomes in the material "Diversity in My Country" grade IV students at SD N 01 Wonorejo, Pekalongan Regency. (Huda et al., 2019) teaching by applying the word guessing learning model can provide better learning outcomes it is seen from the average value of student outcomes, in addition, it can make teaching more effective because students can solve problems about the subject matter given. (Adkhilni \& Mulyadiprana, 2018) Understanding of students who do learning by using word guessing learning models is better than the understanding of students who do learning without using word guessing learning models on social studies subjects the importance of cooperatives in improving community welfare.

Based on this description, it can be said that the guessing model gives a positive impact on learning. So that a research objective is created that analyzes the effectiveness of the guesswork learning model when applied in learning, especially in class IV in Natural Natural sciences. With the hope that by applying this model the teacher will be able to create a learning process that is fun and can be actively involved and can improve student learning outcomes in natural science subjects.

\section{Methodology}

The method used in this study was an experimental research method with a qualitative approach that uses the experimental group and the control group. The steps in this research were by giving different treatments to the experimental group and the control group. In the control class only used conventional learning models while in the experimental class learning used conventional learning models combined with guessing cooperative learning models. After being given different treatment in each class then both classes were given the last test or posttest. Then from the posttest results researcher got a comparison of learning outcomes obtained between the control class and the experimental class.

The sample in this study amounted to 40 people consisting of 2 classes, each with a total of 20 students. The 40 samples before being given care and determined as experimental or control classes were conducted several tests such as the normality test, the test of strength, and different power to determine whether the samples have in common so that this study could be done. After the two research classes namely class IV A as the experimental class and class IV B as the control class was given different treatments in the study and testing for normality and homogeneity is known to have a 
normal and homogeneous distribution. Furthermore, the test carried out was the t-test. This t-test had the objective to find out whether the two classes, namely class IV A experimental class that uses learning with guess word cooperative learning model and class IV B control class that used conventional learning models, had different average learning outcomes or not.

The research method used was the test with a test. This test was given to assess the level of student learning completeness. In this study completeness test, there were 2 types of testing, namely individual learning completeness test or KBI and class learning completeness test or KBK. The individual completeness test or KBI aimed to find out the percentage level of completeness of each student's learners individually while for the class learning completeness test or CBC aimed to determine the percentage level of mastery learning class. In this study completeness test using posttest value data in each research class that had been given a different treatment. The data obtained were then analyzed by the t-test. Before doing the t-test, a preliminary test was used, namely the normality test and the homogeneity test aimed at knowing whether the results of the data were normally distributed and homogeneous so that the hypothesis test could be done.

\section{Finding and Result}

After this research was conducted in which the twelve classes were given different treatments wherein the experimental class was treated in the learning process were treated in the form of guessing words while in the control class without treatment. After being given a posttest they show different mean results where the experimental class had an average higher than the control class. Based on the calculation of the average value of the experimental class and the control class that was $\bar{x} 1=78.4$ and $\bar{x} 2=66.8$ so that the average difference was 11.6.

After calculating the average, the data obtained was tested again before testing the hypothesis. The test carried out was a prerequisite test consisting of a normality test and a homogeneity test. From the normality test, the results of the posttest showed that both were normally distributed. In the experimental class obtained L0 $=0.1048$ with L-table $=0.190$ while for the control class obtained L $0=$ 0.1612 with $\mathrm{L}$-table $=0.190$. From these calculations, it can be concluded that the experimental class and sample control class come from normally distributed populations because L0 <Ltable. Both classes have varying values so that the analysis can proceed to the homogeneity test.

In this final data homogeneity test had the objective to find out whether after being given treatment in the study, the experimental class that was class IV A and the control class that was class IV $B$ had homogeneous data or not. The homogeneity test used posttest value data in each research class that was given different treatment. Based on the calculation results of the homogeneity analysis obtained F-count $=1.110$ with L-table $=4.1$. From these calculations, it can be concluded that the two classes are homogeneous because of Fcount $<\mathrm{F}$ table. This can be interpreted that the two classes namely class IV A and class IV B have relatively the same characteristics.

After the two research classes namely class IV A as the experimental class and class IV B as the control class was given different treatments in the study and testing for normality and homogeneity was known to have a normal and homogeneous distribution. Furthermore, the test carried out was the t-test. This t-test has the objective to find out whether the two classes, namely class IV A experimental class that uses learning with guess word cooperative learning models and class IV B control class that used conventional learning models, have different average learning outcomes or not.

In this t-test used posttest value data in each research class that had been given a different treatment. Based on the calculation results obtained $t=t$ table $=2.028$ because $t$ count $\geq t$ table is $3.2062 \geq 2.028$ then $\mathrm{HO}$ is rejected. It can be concluded that there were differences in learning outcomes between learning using the guess word cooperative learning model with conventional learning on natural natural science subjects. Aside from the t-test calculation, directly visible differences in the average learning outcomes of the two classes through the average posttest learning outcomes obtained after learning, namely for class IV A which was an experimental class had an average value of 78.4 while for class IV B which was the control class had an average value of 66.8. This shows that the average value of learning outcomes for class IV A using the cooperative learning model guess words was better than the average value of learning outcomes for class IV B using conventional learning models.

Furthermore, the last test in this study was the study completeness test. In this learning completeness test, there are 2 types of testing, namely individual learning completeness test or KBI and class learning completeness test or KBK. The individual completeness test or KBI aimed to find out the percentage level of completeness of each student's learners individually while for the class learning completeness test or CBC aims to determine the percentage level of mastery learning class. In this 
study completeness test using posttest value data in each research class that had been given a different treatment. Based on the calculation results of individual learning completeness test analysis that had been done in the experimental class, namely class IV A, it was known that from 20 students there were 19 students declared complete and 1 student not complete. From these data show the level of mastery learning experimental class reached $95 \%$. While based on the results of the calculation of individual learning completeness in the control class that is class IV B it was known that of the 20 students there were 14 students said to be complete and 6 students declared incomplete. From these data shows the level of mastery learning control class only reached $70 \%$. Obtained shows that learning outcomes in the experimental class IV class A are better than learning outcomes in the control class IV class B. Learning outcomes based on the affective assessment of the attitude of the experimental class are superior to the control class seen from a range of class categories and for psychomotor assessment is almost the same in curiosity to explain and report material to each student.

Based on the results of the study obtained data that shows the learning outcomes of class IV-A experimental class is better than the control class IV B. This is because in learning class IV A uses the guesswork cooperative learning model. It can be interpreted that the guesswork cooperative learning model has proven to be effective in learning so that it affects the learning outcomes of students. Guess this cooperative learning model in its implementation using discussion and play methods in solving problems faced in learning.

Based on the research results obtained data that show learning outcomes in the control class that is class IV B is lower than the experimental class that is class IV A. This is because in learning in the control class only uses conventional models that are simple and less varied causing students to become bored while learning takes place so that students often do not pay attention when the teacher explains the learning material. The conventional learning model is also lacking to make students active in learning so that students are more passive. The teacher only explains by lecturing continuously so that it causes students to become bored and instead play along with other students as a result students become less able to understand the material eventually get a low grade. Evidenced by the acquisition of control class learning outcomes that are lower than the experimental class. The mastery learning control class is also lower than the experimental class. This statement is following the statement (Latief, 2016) The conventional learning process is carried out as in which the teacher generally teaches the material to his students, it is the teacher who transfers students' knowledge to passive listening. The argument of (Ibrahim, 2017) of the conventional learning model is teacher-centered learning, prioritizing results rather than processes, students are placed as objects and not subject to learning so that students find it difficult to express their opinions.

While the experimental class showed higher results compared to conventional models, this is inseparable from the use of word guessing models. Guess the word model is one of the cooperative learning models in which the learning process is combined with word guessing games. Guess the word learning model that is one example of cooperative learning in which the learning process guesses a word by mentioning certain words until the words mentioned are correct, (Hanif Mukhlas, 2018). Guess the word model is a game-based cooperative learning model that matches the character of elementary school students (Syamsiyah \& Wedyawati, 2017). (Ryantika, et., al., 2016 (Adkhilni \& Mulyadiprana, 2018) states that the guess word model is a learning model is a cooperative model that emphasizes more on making vocabulary students more students because students are required to answer questions in the form of few clues. The uniqueness of the word guessing model makes students more active and makes the learning process more fun (Adkhilni \& Mulyadiprana, 2018). So the word guessing model is one of the cooperative models that is packed with word guessing games where students are required to guess the whole word by arranging or completing words with letters. With this model, students will be more active in the learning process and students will increase knowledge about vocabulary, development of collaborative skills, and develop thinking skills and the ability to submit an opinion (Suryadi, 2019). This is supported by (Fadhillah, 2019) who states that the guesswork model can increase students' motivation in finding words to be arranged in sentence form. So it can be said that this word-guessing model requires students to learn more actively to complete the words used as questions.

With the learning process combined with the game will make students comfortable and happy to follow the learning, this will have an impact on children's cognitive and social development. Tedjasaputra (2001:20) (HAmbali \& Sutiswo, 2019) said that: Through play also children understand the relationship between themselves and their social environment, learning to get along and understand the rules or procedures for the association are closely related to the cognitive development of children. Learning that contains elements of the game can allow students to learn in groups and be directly involved in the learning process (Desmita, 2012:35(Apriyanti, Lisa, 2019)). Meanwhile, 
(Aryati, 2019) Through play can teach you how to understand life, control yourself, solve problems, communicate, can develop motor and cognitive dimensions and creativity, can find and learn to fun new things. So, with the game students will be happier to learn given the characteristics of elementary school children who are still in the stage of playing. Besides guessing learning models also have advantages.

(Kurniasih, 2017) Guess the word model has several advantages namely, children will have a wealth of languages, very interesting so that each student wants to try it, students become interested in learning, and makes it easy to instill the concept of learning in students' memories. The strength of the guesswork model is also supported by several studies. Where the studies stated that the general guess of the word guess model will have a positive impact on the learning process because students actively find and arrange knowledge about word literacy, the learning process is more fun because students play in learning,(Fadhillah, 2019; Ferianti \& Hamzah, 2018; Suryadi, 2019). The success of the guessing word learning model is inseparable from the steps of learning that are carried out. Suprijono (Suryadi, 2019) Expressing the steps of Guess the Word Learning Model are: 1) The teacher explains the competency to be achieved or material approximately 45 minutes. 2) The teacher tells students to stand in pairs in front of the class. 3) A student is given a card measuring $10 \times 10 \mathrm{~cm}$ which his partner will read out later. Another student is given a $5 \times 2 \mathrm{~cm}$ card whose contents cannot be read (folded) then placed on the forehead or tucked in the ear. 4) While students carry a $10 \times 10 \mathrm{~cm}$ card read out the words written in it while the partner guesses what is meant in the $10 \times 10 \mathrm{~cm}$ card, the right answer if it matches the contents of the card affixed to the forehead or ears. Seeing the advantages possessed by the guesswork model, many studies have been done before.

Research conducted by (Mursidik et al., 2015) found that the guessing model influences student learning outcomes in simple aircraft material class V SDN 02 Lengkenat this is seen based on the t-test where $t$ count is greater than $t$ table that is 2.816> 2.042. (Fitri et al., 2018) There is an influence of guessing learning models supported by comic media on Indonesian language learning outcomes material describing animals around according to their characteristics using sentences that are easily understood in class II students of SDN III Panjerejo 2016/2017 Academic Year evident from the value of t-count 5.947 is greater than t-table 1\%, namely 1.2931. While the Experimental group's mean test is 85.5263. While the mean test of the control group is 72.9474. (Hanif Mukhlas, 2018) stated that the effectiveness of the guesswork learning model on learning outcomes in the material "Diversity in My Country" grade IV students in SDN 01 Wonorejo, Pekalongan Regency. (Huda et al., 2019) teaching by applying a model of guessing learning can provide better learning outcomes it is seen from the average value of student outcomes, in addition, it can make teaching more effective because students can solve problems about the subject matter given. (Adkhilni \& Mulyadiprana, 2018) Understanding of students who do learning using guessing learning models is better than understanding students doing learning without using guessing learning models in social studies subjects the importance of cooperatives in improving community welfare.

\section{Conclusion}

Based on the results of research that has been carried out in class IV SD Negeri Kedungpucang Purworejo, it can be concluded that the use of a guessing cooperative learning model is effective on the learning outcomes of Natural Natural sciences in class IV students of Kedungpucang Purworejo State Elementary School in 2019/2020. From the analysis of the final data that is using the t-test t-table that is $2.2062 \geq 2.028$. So there is a difference in learning outcomes that use the cooperative learning model of guessing words with conventional learning models in natural science subjects. Interpreting the learning outcomes of experimental class IV A is higher than the learning outcomes of control class IV B. Based on the results of the study, the suggestions that can be submitted are as follows: (1) Teachers should be able to use the cooperative learning model of guess words because with this model it is proven can improve learning outcomes. (2) Teachers should need to improve student learning outcomes by choosing appropriate learning models, fun, activating students so that students' understanding is better. (3) this research is expected to be used as a reference for further research so that the quality of future research will be better.

\section{References}

Adkhilni, N. M., \& Mulyadiprana, A. (2018). Pengaruh Model Pembelajaran Tebak Kata terhadap Pemahaman Siswa pada Materi Mengenal Pentingnya Koperasi dalam Meningkatkan Kesejahteraan Masyarakat. Pedadidaktika: Jurnal Ilmiah Pendidikan Guru Sekolah Dasar, 5(1), 
286-295.

Agus Suprijono. (2014). Cooperative Learning: Teori dan Aplikasi PAIKEM. Pustaka Pelajar.

Ahmad, S. (2013). Teori Belajar dan Pembelajaran di Sekolah Dasar. Kencana Prenada Media Group.

Apriyanti, Lisa, A. G. \&Feri N. (2019). Pengaruh Permainan Ular Tangga Terhadap Hasil Belajar Matematika Siswa Kelas IV di SDN 51 Kota Bengkulu. Jurnal Riset Pendidikan Dasar, 2(1), 8-15. https://ejournal.unib.ac.id/index.php/juridikdasunib/article/view/7269/3548

Aryati, V. A. (2019). Pengaruh Permainan Tradisional Terhadap Hasil Belajar Lari Jarak Pendek Siswa Smp Negeri 7 Kota Sukabumi. Indonesia Spor Journal, 2(2), 39-48.

Asmadawati. (2014). Perencanaan Pengajaran. Darul Ilmi, 02(01), 1-13.

Dolong, H. M. J. (2016). Teknik analisis dalam komponen pembelajaran. Jurnal UIN Alauddin, 5(2), 293300.

Fadhillah, D. (2019). Pengaruh Metode Tebak Kata terhadap Keterampilan Menulis Puisi Siswa Kelas IV SDN Taman Cibodas Kota Tangerang. Silampari Bisa: Jurnal Penelitian Pendidikan Bahasa Indonesia, Daerah, Dan Asing, 2(1), 118-128. https://doi.org/10.31540/silamparibisa.v2i1.332

Ferianti, F., \& Hamzah, A. (2018). Model Pembelajaran Cooperative Learning Tipe Tebak Kata Terhadap Hasil Belajar Siswa Mata Pelajaran Bahasa Arab di MIN Kemu OKU Selatan. JIP: Jurnal Ilmiah PGMI, 3(2), 134-143. https://doi.org/10.19109/jip.v3i2.1647

Fitri, A., Muda, I., \& Badaruddin. (2018). The Influence of Good Corporate Governance, Leverage, and Profitability on Earning Management with Firm Size as Moderating Variable in the Banking Companies Listed In Indonesia Stock Exchange from 2012 to 2016. International Journal of Research and Review, 5(9), 49-66. https://doi.org/10.4444/ijrr.1002/747

HAmbali, S. \&, \& Sutiswo. (2019). Pengaruh Metode Bermain Terhadap Hasil Belajar Passing Bawah Bola Voli Di Sekolah Dasar. Perspektif Ilmu Pendidikan, 33(1), 27-32. https://doi.org/doi.org/PIP.331.3

Hanif Mukhlas, M. (2018). Keefektifan Model Pembelajaran Tebak Kata Terhadap Hasil Belajar Pada Tema 7 "Indahnya Keragaman Di Negeriku" Siswa Kelas Iv. Mimbar Ilmu, 23(3), 200-207. https://doi.org/10.23887/mi.v23i3.16436

Huda, A. K., Reffiane, F., \& Untari, M. F. asri. (2019). Keefektifan Model Pembelajaran Tebak Kata Terhadap Hasil Belajar Ipa Siswa Kelas Iii Sd Negeri Rejosari 03 Kota Semarang. Malih Peddas (Majalah Ilmiah Pendidikan Dasar), 8(2), 171. https://doi.org/10.26877/malihpeddas.v8i2.3072

IBRAHIM. (2017). Perpaduan Model Pembelajaran Aktif Konvensional .... 3(2), 199-212.

Kurniasih, I. dan B. S. (2017). Ragam Pengembangan Model Pembelajaran. Kata Pena.

Latief, H. (2016). Pengaruh Pembelajaran Kontekstual Terhadap Hasil Belajar (Studi Eksperimen Pada Mata Pelajaran Geografi Kelas Vii Di Smpn 4 Padalarang). Jurnal Geografi Gea, 14(2), 14-28. https://doi.org/10.17509/gea.v14i2.3395

Marlina, L. (2017). Perencanaan Pembelajaran Pendidikan Anak Usia Dini. Raudhatul Athfal: Jurnal Pendidikan Islam Anak Usia Dini, 1(2). https://doi.org/10.19109/ra.v1i2.2679

Mursidik, E. M., Samsiyah, N., \& Rudyanto, H. E. (2015). Creative Thinking Ability in Solving OpenEnded Mathematical Problems Viewed From the Level of Mathematics Ability of Elementary School Students. PEDAGOGIA: Journal of Education, 4(1), 23. www.journal.umsida.ac.id

Rencus B. Sinabariba. (2017). Peranan guru memilih model-model pembelajaran untuk meningkatkan kemampuan menulis puisi. Seminar Nasional Pendidikan Dasar Universitas Negeri Medan, 3-10. http://osf.io

Suryadi. (2019). Peningkatan Hasil Belajar Ipa Melalui Model Pembelajaran Kooperatif Tipe Tebak Kata. Jurnal Inovatif Ilmu Pendidikan, 1(1), 67-82.

Syamsiyah, N., \& Wedyawati, N. (2017). Pengaruh Model Pembelajaran Kooperatif Tebak Kata Pesawat Sederhana Kelas V. Vox Edukasi, 8(1), 30-41. 
Widia Hapnita, Rijal Abdullah, Yuwalitas Gusmareta, F. R. (2018). Faktor Internal Dan Eksternal Yang Dominan Mempengaruhi Hasil Belajar Menggambar Dengan Perangkat Lunak Siswa Kelas Xi Teknik Gambar Bangunan Smk N 1 Padang Tahun 2016/2017. Cived, 5(1).

Zein, M. (2016). Peran guru dalam pengembangan pembelajaran. Journal UIN-Alauddin, V(2), 274-285. https://doi.org/10.24252/ip.v5i2.3480 